\title{
TEACHING ENGLISH FOR AGRICULTURE THROUGH PROVERBS IN L1 AND L2
}

\author{
O ensino de inglês para agricultura através de provérbios em \\ I1 e L 2
}

\author{
Vivina Almeida Carreira' \\ Odete Burgeile²
}

\begin{abstract}
This paper addresses the role of translation and mother tongue as fruitful teaching and learning resources in the case of English for Specific Purposes, particularly the study and translation of proverbs in the process of teaching and learning English for agriculture. Proverbs, as tradition handed down from generation to generation, act as a way of identifying, in different manners of expression, deep roots of cultural influence, as well as perceiving undercurrents of ideas ethical, political, aesthetic, literary, scientific, etc. - in the history of peoples' cultures. Agriculture is a rich field of proverbial heritage in most cultures, and so proverbs can most productively be used for various purposes within the English class. From conveying the difference between linguistic and cultural competence, linguistic and idiomatic meaning, literal and figurative language, written and spoken language to vocabulary acquisition and retention, proverbs can unfold in a multitude of classroom activities demonstrating their huge application potential and didactic power.
\end{abstract}

Keywords | English for specific purposes. Language teaching. Pedagogical translation. Proverbs. Specialised languages.
Resumo | Este artigo aborda o papel da tradução e da língua materna como recursos frutíferos de ensino e aprendizagem no caso do inglês para fins específicos, particularmente o estudo e tradução de provérbios no processo de ensino e aprendizagem de inglês para agricultura. Os provérbios, como tradição transmitida de geração em geração, atuam como forma de identificar, de diferentes maneiras de expressão, raízes profundas da influência cultural, bem como perceber as tendências subjacentes de ideias - éticas, políticas, estéticas, literárias, científicas, etc. - na história das culturas das pessoas. A agricultura é um campo rico de herança proverbial na maioria das culturas e, portanto, os provérbios podem ser utilizados de forma mais produtiva para vários fins dentro da aula de inglês. Ao mostrar a diferença entre competência linguística e cultural, significado linguístico e idiomático, linguagem literal e figurativa, linguagem escrita e falada para a aquisição e retenção de vocabulário, os provérbios podem se desdobrar em uma infinidade de atividades em sala de aula demonstrando seu enorme potencial de aplicação e poder didático.

Palavras-chave I Inglês para fins específicos. Ensino de línguas. Tradução pedagógica. Provérbios. Linguagens especializadas.

1 Carreira. Polytechnic Institute of Coimbra. E-mail: vivina@esac.pt

2 Burgeile. University of Rondônia. E-mail: odetebur@gmail.com 
- | Teaching english for agriculture through proverbs in I1 and I2

\section{Introduction}

The study of description, classification, etymology and pragmatics of proverbs is called paremiology (from Greek $\pi \alpha \rho$ poú $\alpha$ - paroimía, "proverb") and can be dated back to Aristotle's times. In modern times, contrary to what one might expect, the continuity of this interest is clearly visible in the numerous articles, essays, papers, books, collections, associations and conferences that are dedicated to the study of proverbial texts applied in different fields of knowledge - sociology, anthropology, philosophy, cultural studies, linguistics, pedagogy, and translation studies, to name but a few.

The premise that proverbs play an important role in language teaching as they can be used as a means to acquire vocabulary as well as a means to gain cultural knowledge, metaphorical understanding and communicative competence is also present in many influential studies such as Hanzén (2007); Hulstijn (1992); Joe (1995); Hulstijn and Laufer (2001); and Nuessel (2003), among others.

Proverbs and sayings can be used in any stage of a lesson - as in warm-up activities, to present and practice lexical items and grammar structures, to practice pronunciation, to trigger a discussion or a debate, as a resource for project work or essay writing. Proverbial texts are short, funny and they often rhyme, making the learning process easier and more effective. Besides, they are also powerful instruments to provide cultural awareness.

The use of proverbs in language teaching also entails another kind of discussion that pertains to the use of mother tongue in foreign language teaching. The debate over the controversial theme of using translation in language teaching has been widely presented and summarized by several scholars, inter alia Richards et al. (1986); Duff (1989); Stern et al. (1992); Malmkjaer (1998); Cook (1998); Mahmoud (2006), and Butzkamm and Caldwell (2009).

These are the main issues that will be addressed in this study, which has been motivated by a continued experience in teaching scientific and technical English, particularly for first-year students of Agricultural Engineering. Being this field one with a strong proverbial heritage, the authors strongly propose and justify the resource of proverbs as tools for gaining linguistic, communicative and cultural competence. 


\title{
The importance of proverbs
}

Closely linked to the cultural and linguistic history of a community, the proverb is a short, concise and sententious text, which is transmitted orally from generation to generation and eventually acquires the condition of an anonymous fixed text. Proverbs express views of the world, timeless truths that are generalized from regular actions and behaviors and widely accepted by the community. As a highly regarded paremiologist puts it, "a proverb is a short, generally known sentence of the folk which contains wisdom, truth, morals, and traditional views in a metaphorical, fixed and easily- remembered form and which is handed down from generation to generation" (MIEDER, 2004, p. 3).

The same scholar states that proverbs derive from a human need to communicate experience:

\begin{abstract}
Proverbs fulfill the human need to summarize experiences and observations into nuggets of wisdom that provide readymade comments on personal relationships and social affairs. There are proverbs for every imaginable context, and they are thus as contradictory as life itself. Proverb pairs like "Absence makes the heart grow fonder" and "Out of sight, out of mind" or "Look before you leap" and "He who hesitates is lost" make it abundantly clear that proverbs do not represent a logical philosophical system. But when the proper proverb is chosen for a particular situation, it is bound to fit perfectly and it becomes an effective formulaic strategy of communication (MIEDER, 2004, p. 1).
\end{abstract}

Contrary to what might be expected, modern society does not dispense with proverbs. As Mieder points out "proverbs are a significant rhetorical force in various modes of communication, from friendly chats, powerful political speeches, and religious sermons to lyrical poetry, best-seller novels, and the influential mass media. Proverbs are in fact everywhere, and it is exactly their ubiquity that has led scholars from many disciplines to study them from classical times to the modern age" (ibidem).

Proverbial texts are keepers of a cumulative and empirical knowledge that for centuries filled scientific knowledge gaps. There are proverbs that refer to every aspect of human life, feeling and thought. Their role in building the identity of the 
- | Teaching english for agriculture through proverbs in I1 and I2

communities in which they emerge cannot be denied. The proverbial analysis gives us access to aspects that make up their worldview. That is, they allow us to interpret the experience of a given community through revelation of their food preferences and habits, their symbolic-religious capital, their prejudices, their weather forecasting methods and farming techniques.

\section{The use of mother tongue and translation in language teaching}

Not long ago, translation was still banned from the classroom and with that, the mother tongue was thought to have disappeared from the process of learning a foreign language. But, in fact, that is not possible. The mother tongue pervades all our cognitive acts. One cannot deny its omnipresence in any cognitive act, particularly well instanced in the involuntary translation that occurs in the process of learning a foreign language, by way of which the learner establishes spontaneous and unavoidable contrastive relations between the two linguistic systems. In learning a foreign language, comparing with the mother tongue is unavoidable. And that is not necessarily bad, in reverse, as stated by Duff:

\footnotetext{
We all have a mother tongue, or first language. This shapes our way of thinking, and to some extent our use of the foreign language (pronunciation, choice of words, tone, word order, etc.). Translation helps us to understand better the influence of the one language on the other, and to correct errors of habit that creep in unnoticed (such as the misuse of particular words or structures). And, because translation involves contrast it enables us to explore the potential of both languages - their strengths and weaknesses. (DUFF, 1989, p. 6)
}

According to Butzkamm (2003), our first language plays a role so important that it determines the way we learn other languages, as it builds the first base for reference. As he puts it, "we only learn language once" and he presents his theory:

\footnotetext{
Using the mother tongue, we have (1) learnt to think, (2) learnt to communicate and (3) acquired an intuitive understanding of grammar. The mother tongue opens the door, not only to its own grammar, but to all grammars inasmuch as it awakens the potential for universal grammar that lies within all of us. This foreknowledge is the result of
} 
interactions between a first language and our fundamental linguistic endowment and is the foundation on which we build our Selves. It is the greatest asset people bring to the task of foreign language learning. For this reason, the mother tongue is the master key to foreign languages, the tool which gives us the fastest, surest, most precise, and most complete means of accessing a foreign language. (BUTZKAMM, 2003, p. 1-2)

Some of the authors that ascribe to mother tongue an important role in the foreign language classroom defend that it is particularly useful in an early age and at the beginning of the learning process (GREEN, 1970; ATKINSON, 1987). We have shown elsewhere (FIGUEIREDO, 2005, 2007), that translation is an efficient pedagogical tool particularly in the learning of a specialised language, and most useful at intermediate levels and in an adult stage, as students may take advantage of their cognitive abilities which they already use in their native language learning.

According to Cook, bilingualism-related activities "by relating new to existing knowledge, [...] will also give intermediate students a sense of confidence in what they know and of order in what they are learning" (COOK, 2010, p. 132). At an adult stage, the mother tongue can be used "to provoke discussion and speculation, to develop clarity and flexibility of thinking, and to help us increase our own and our students' awareness of the inevitable interaction between the mother tongue and the target language that occurs during any type of language acquisition" (DUFF, 1989).

Titford (1983) also sees translation as a "problem-solving exercise" which raises students' awareness by comparing and contrasting the mother tongue with the target language. Through this problem-solving, students can increase "their feelings for communicative appropriateness in the L2" (TITFORD, 1983, p. 56). Titford argues that his techniques are not alternatives to more communicative tasks, but have the potential to consolidate language and open the way to more communicative follow-up activities.

Mahmoud (2006, p. 30) argues that translation can be used as a productive means to learn new vocabulary in a second language and he advances a number of principles which support the use of translation in second language acquisition, namely, that translation uses authentic materials, is interactive, learner-centered and promotes learner autonomy. Other scholars have similarly identified ownlanguage use as the most effective way of learning vocabulary, via learners' use of bilingual dictionaries and also as a teaching strategy (inter alia BENSON, 2003; LEONARDI, 2010; NATION, 2003; LAUFER; GIRSAI, 2008 and HALL; COOK, 2012). 
- | Teaching english for agriculture through proverbs in I1 and I2

\title{
The use of proverbs in language teaching
}

Many scholars consider that proverbs should be used in teaching as didactic tools because, as Mieder (2004, p. 146) puts it, "they belong to the common knowledge of basically all native speakers, they are indeed very effective devices to communicate wisdom and knowledge about human nature and the world at large". When it comes to foreign language teaching and learning, the use of proverbs is strongly recommended by various scholars who call attention to some characteristics of these texts that enhance foreign language learning in a wide range of areas: grammar and syntax, phonetics, vocabulary development, culture, reading, speaking and writing (BYRAM et al., 2002; HANZÉN, 2007; MITCHELL, 2014). Mieder (2004, p. 147) states that:

\begin{abstract}
Proverbs also play a major role in the teaching of English as a second language, where they are included as part of metaphorical and cultural learning. Obviously it behooves new speakers of English to be acquainted with proverbs and other phraseological units for effective communication. As instructors plan the curriculum and devise textbooks for teaching English as a second language, they should choose those proverbs for inclusion that are part of the AngloAmerican paremiological minimum. It is the proverbs that are in use today that ought to be taught.
\end{abstract}

Litovkina (2000 apud HANZÉN, 2007) also states that proverbs, more than being an important part of culture are also a significant tool to effectively communicate and to comprehend different spoken and written discourses. Litovkina's most important argument is that the person who does not acquire competence in using proverbs will be limited in conversation, will have difficulty to comprehend a wide variety of printed matter, radio, television, songs etc., and will not understand proverb parodies which presuppose a familiarity with a stock proverb. 


\section{Communicative and cultural competence}

The learner of a foreign language needs to be aware of its cultural idiosyncrasies in order to communicate effectively. Communicative competence requires not only knowledge of the vocabulary and the grammar of a language, but also to know how to use it adequately in different sociocultural situations. To learn a proverb fully entails much more than to understand its meaning; "the real linguistic task begins when the language learner attempts to learn when and how to apply the proverb to a concrete communicative situation" (NUESSEL, 2003, p. 399).

Teaching a foreign language can only be successful by developing learners' cultural awareness, and one possible approach to that is using authentic texts. There are many examples of authentic texts that can be successfully used in class, e.g., short stories, newspaper articles, poems, advertisements, leaflets, brochures, announcements, etc. But proverbs are the shortest examples of authentic texts.

Raymond (1948) also presents strong arguments for using proverbs as a teaching device. Proverbs are not only melodic and witty, possessed with rhythm and imagery; proverbs also reflect "patterns of thought" (RAYMOND, 1948, p. 522). As proverbs are universal, there are similar proverbs in different nations that have related cultural patterns. E.g. All cats are grey in the dark (whose Portuguese equivalent displays a subtle variation (De noite todos os gatos são pardos), which suggest a universal value that beauty is unimportant. Or, A bird in the hand is worth two in the bush (Mais vale um pássaro na mão do que dois voando) with the universal meaning that one should not trade the certain for the uncertain.

In some cases, similarities can occur at the phraseological level and at other times at the semantic level. There is not always a direct correspondence, so the proverbial text is a way of demonstrating that the translation cannot be literal, allowing to compare and contrast L1 with L2. A good exercise for students is to explore a few examples of proverbs with the same meaning, but with nonexistent lexical equivalence. E.g.: The grass is always greener on the other side of the fence (Agalinha da vizinha é sempre melhor que a minha); The early bird catches the worm (Deus ajuda quem cedo madruga).

Another good worksheet would be to ask the students to compile a list of proverbs on the same topic and with the same or similar meaning. E.g., Sow the 
- | Teaching english for agriculture through proverbs in I1 and I2

wind and reap the whirlwind (Quem semeia ventos colhe tempestades)/ As you sow, so shall you reap/One man sows and another reaps/ As you make your bed so you must lie on it.

Proverbs can also be used to show that each culture has their own set of proverbs and that they also translate geographical and weather idiosyncrasies, as can be illustrated with the Brazilian adaptation of a general proverb for the region of Ceará - Abril, águas mil, ou coadas por um funil (In April a thousand waters, or strained through a funnel), alluding to the climatology of Ceará where there may be as much rain as almost none.

On the other hand, the use of proverbs also provides a historical perspective of the traditions of a culture as "many proverbs refer to old measurements, obscure professions, outdated weapons, unknown tools, plants, animals, names, and various other traditional matters" (MIEDER, 2004, p. 137). A good example of how to use a proverb to demonstrate historical relevance and also that some proverbs are not universal but pertain to only one or two cultures is the Portuguese proverb De Espanha nem bom vento nem bom casamento, which means: "From Spain, neither good wind, nor good marriage", which contains in itself centuries of history of unfriendly relations between the two countries, which at present does not occur. This example can be used to deconstruct this misconception, and to show that proverbs sometimes suffer from a chronological fixity and cease to make sense, being nevertheless useful to foster critical thinking.

The proverbial text allows thus to detect and analyze evidence of prejudices and misconceptions, opening the way to their deconstruction. Raymond challenges learners: "Let each student seek and discover meanings, beauty or wit or culture in his own manner by suggestion and inference in accordance with his background" (RAYMOND, 1948, p. 523). More recently, Byram et al. have further deepened the sense of a teaching-learning process based on awareness of the intercultural dimension and its positive social effects:

\footnotetext{
The intercultural dimension is concerned with - helping learners to understand how intercultural interaction takes place, - how social identities are part of all interaction, - how their perceptions of other people and other people's perceptions of them influence the success of communication - how they can find out for themselves more about the people with whom they are communicating (BYRAM et al., 2002, p. 10).
} 


\section{Linguistic and figurative meaning}

Communicative competence is connected to both cultural knowledge and metaphorical understanding. We can use proverbs to exemplify grammatical issues, to establish contrastive relations between different linguistic systems, to practice pronunciation, to teach vocabulary, to exercise creative language but, above all, we can use them to approach figurative meaning.

Figurative language includes metaphors, similes, sayings and proverbs and is a part of everyday language and it is often a problem to foreign language learners due to its underlying metaphorical nature. Failing to understand figurative language can cause misunderstanding and miscommunication or cognitive breakdown towards a text or a speech and ultimately, it can result in frustration and demotivation. Some scholars argue that one way of developing figurative and metaphorical understanding is by using proverbs in the teaching of a foreign language, as "the vast majority of proverbial sayings are metaphorical" (GIBBS; BEITEL, 2003, p. 116) and because a characteristic of proverbial language is its extensive reliance on figurative speech (NUESSEL, 2003, p. 402). Good examples of proverbs to explain denotative and figurative meanings would be: An old ox makes a straight furrow (Someone who is old will usually be more experienced in everything) or Don't count your chickens before they hatch (Do not count on something before it happens).

\section{Vocabulary acquisition and retention}

To learn a new word - and retain it - entails much cognitive effort on the part of the students. For as many different strategies and techniques we may use, their effectiveness depends on many variables and one of the most important of them is the extent to which the students engage in continuous, active and systematic study of the target vocabulary. One of the problems that students mostly face is that they easily forget the newly learned words. A proverb is usually recognized by the fixed, often short form and contains frequently used vocabulary, and therefore is quite easy to memorize (BAHARIAN et al., 2014). 
- | Teaching english for agriculture through proverbs in I1 and I2

As far as vocabulary retention is concerned, Hulstijn (1992) demonstrated that target vocabulary items were retained significantly longer when their meanings were correctly inferred than when they were explained. Joe (1995) advanced that the retention of unfamiliar words was significantly facilitated when students engaged in a text-based task that demanded a higher level of generativity. In the same line, Hulstijn and Laufer (2001) demonstrated that students who participated in a composition task could retain target words better than those engaged in a reading comprehension or fill-in task.

Teaching vocabulary through using proverbs can be an effective technique. As part of formulaic language, proverbs can inspire fluent and natural language production and cause students to be more motivated as they are learning authentic language, which they can use in both oral and written communication.

\section{Class activities}

Working with proverbs can help to diversify the educational process. Proverbs are pregnant with meaning and can be decoded, read, and interpreted in many different ways. Their potential for multitasks (coding, decoding, interpretation, translation, etc.) is huge. Besides providing a way into grammar and linguistic items (e.g. No news is good news), they can help in forming critical thinking and can convey intercultural awareness as they are carriers of wisdom and values from different cultures.

There are many activities that can be developed in a foreign language class. Interpretation exercises can be carried out wherein the teacher asks a student to tell a proverb in his/her mother tongue asks another student to translate it into English and asks the class to interpret the proverb in English. To find the English equivalence of a proverb in the students' mother tongue (or vice-versa) is always a very challenging and motivating activity. Other activities can be to match the part one with part two, fill-in the blanks, write a paragraph with an English proverb as a topic sentence, make up a story for a proverb, etc. 


\section{Agriculture - a rich field of proverbial heritage}

Agriculture is certainly a rich field of proverbial texts, there being proverbs in most civilizations about farming techniques, animal husbandry, the weather and time in relation to crop production, and most of the times these proverbs contain literal and metaphoric meanings.

Within the scope of the English forSpecific Purposes class with undergraduate students taking an Agriculture Engineering degree, a project work was carried out involving proverb study that lasted for 4 months, occupying the last part of the lessons. Each month, each student had to introduce a Portuguese farming-related proverb, explain its meaning, developing paraphrasing skills, and the whole class would have to find out its equivalent in English. Comparison between the two proverbs was encouraged on the basis of establishing the differences and similarities between the two languages and cultures.

As a follow-up activity, each student would fill-in a worksheet designed to generate a wordbook/thesaurus, which included both formulations of the proverb, its explanation/paraphrase as well as words connected to the topic nouns, adjectives and verbs (Table 1).

Students from abroad contributed with proverbs from their countries. By the end of the term, the class managed to gather ninety-six farming-related proverbs in Portuguese and in English and benefited from generating a wordbook of related vocabulary. In the end, the proverbs, in both languages, were written in broad bands and placed on the walls of the classroom, which was also a motivating final element to it. 
- | Teaching english for agriculture through proverbs in I1 and I2

Table 1 - Example of a worksheet designed in this project to generate a wordbook from proverbs

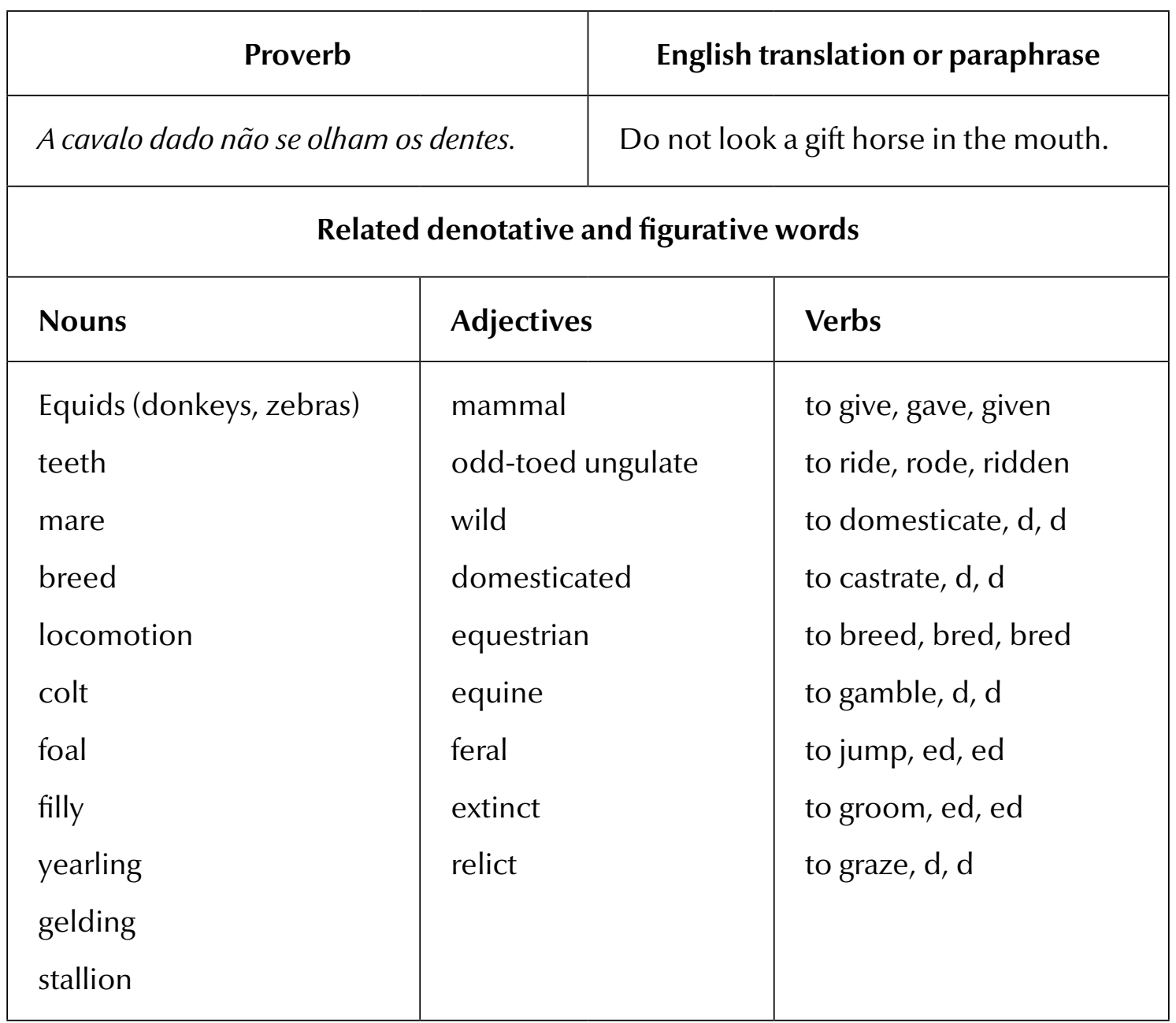

Source: produced by the authors 


\section{Final considerations}

This work aimed to show the didactic power of proverbs. As there aren't always exact equivalences, it can be showed to the students that the translation of a formulaic expression must be made on the basis of an equivalent expression in the target language and not on a literal way; at the same time, it showed them that the translation of formulaic expressions requires more cultural knowledge than the non-formulaic expressions.

By looking for equivalent versions of the proverbs, students can also expand their vocabulary knowledge and as they write the different words down, it allowed for more retention, as well as more awareness of the different morphologic categories of words.

By discovering the cultural and traditional values underlying the literal words, students can have the opportunity to work out the similarities and differences between two cultures that are reflected through their proverbs. From these, they are able to build cross-cultural knowledge that can effectively serve their communicative purposes in daily-life as well as in professional and international contexts.

\section{References}

ATKINSON, A. The mother tongue in the classroom: a neglected resource? ELT Journal, 41/4, p. 241-247, 1987.

BAHARIAN, E.; REZAI, M. J. The effect of proverbs on learning vocabulary through visual organizers. International Journal of English Language Teaching, v. 2, n. 4, p. 16-32, 2014.

BENSON, P. Learner autonomy in the classroom. In: NUNAN, D. (Ed). Practical English Language Teaching. New York: McGraw-Hill, 2003. p. 289-308.

BUTZKAMM, W. We only learn language once. The role of the mother tongue in FL classrooms: death of a dogma. Language Learning Journal, n. 28, p. 29-39, 2003.

BUTZKAMM, W.; CALDWELL, J. The Bilingual Reform. A Paradigm Shift in Foreign Language Teaching. Tübingen: Gunter Narr Verlag, 2009. 
- | Teaching english for agriculture through proverbs in I1 and I2

BYRAM, M.; GRIBKOVA, B.; STARKEY, H. Developing the Intercultural Dimension in Language Teaching. A Practical Introduction for Teachers. Strasbourg: Council of Europe, 2002.

COOK, G. Use of Translation in Language Teaching. In: BAKER, M. (Ed). Routledge Encyclopedia of Translation Studies. London: Routledge, 1998. p. 117-120.

COOK, G. Translation in Language Teaching. Oxford: Oxford University Press, 2010.

DUFF, A. Translation. Oxford: Oxford University Press, 1989.

FIGUEIREDO, V. A. tradução como recurso no ensino do Inglês técnico-científico. Specific. Revista de Inglês para Fins Específicos, 2, p. 93-100, 2005.

FIGUEIREDO, V. A. dimensão pragmática da tradução no ensino-aprendizagem da língua estrangeira especializada. Tradução e Comunicação. Revista Brasileira de Tradutores, 16, p. 101-107, 2007.

GIBBS, R. W.; BEITEL, D. What proverb understanding reveals about how people think. In: MIEDER, W. (Ed). Cognition, Comprehension and Communication. A Decade of North American Proverb Studies (1990-2000). Hohengehren: Schneider-Verlag, 2003. p. 3752.

GREEN, J. The use of the mother tongue and the teaching of translation. ELT Journal, 24, p. 217-223, 1970.

HALL, G.; COOK, G. Own language in Language Teaching and Learning: State of the Art. Language Teaching, 45/3, p. 271-308, 2012.

HANZÉN, M. When in Rome, Do as the Romans Do - Proverbs as a Part of EFL Teaching. 2007. Disponível em: <http://www.diva-portal.org/smash/get/diva2:3499/fulltext01. pdf>. Acesso em: 06 jul. 2016.

HULSTIJN, J. H. Retention of inferred and given word meanings: Experiments in incidental learning. In: ARNAUD, P.; BEJOINT, H. (Ed). Vocabulary and Applied Linguistics. London: MacMillan, 1992. p. 113-125.

HULSTIJN, J. H.; LAUFER, B. Some empirical evidence for the involvement load hypothesis in vocabulary acquisition. Language learning, 51(3), p. 539-558, 2001.

JOE, A. Text-based tasks and incidental vocabulary learning. Second Language Research, 11, p. 149-158, 1995.

LAUFER, B.; GIRSAI, N. Form-focused Instruction in Second Language Vocabulary Learning: A case for Contrastive Analysis and Translation. Applied Linguistics, 29(4), p. 694-716, 2008. 
LEONARDI, V. The role of Pedagogical Translation in Second Language Acquisition. From Theory to Practice. Bern: Peter Lang, 2010.

MAHMOUD, A. Translation and Foreign Language Reading Comprehension: A Neglected Didactic Procedure. English Teaching Forum, n. 4, p. 28-34, 2006.

MALMKJAER, K. (Ed.). Translation and Language Teaching. Language Teaching and translation. Manchester: St. Jerome Publishing, 1998.

MIEDER, W. Proverbs: A handbook. Westport: Greenwood Publishing Group, 2004.

MITCHELL, C. The potential of metaphor in ESL pedagogy. A pilot case study. Connexions. International Professional Communication Journal, 2(1), p. 75-87, 2014.

NATION, P. The role of the first language in foreign language learning. Asian EFL Journal, 5/2, p. 1-8, 2003.

NUESSEL, F. Proverbs and metaphoric language in second-language acquisition. In: MIEDER, W. (Ed.). Cognition, Comprehension and Communication. A Decade of North American proverb Studies (1990-2000). Hohengehren: Schneider-Verlag, 2003. p. 395412.

RAYMOND, J. Proverbs and language teaching. Modern Language Journal, 32, p. 522-523, 1948.

RICHARDS, J.; RODGERS, T. Approaches and Methods in Language Teaching. 1986.

STERN, H.; ALLEN, P.; HARLEY, B. Issues and Options in Language Teaching. Oxford: Oxford University Press, 1992.

TITFORD, C. Translation for advanced learners. ELT Journal, 37/1, p. 52-57, 1983.

COMO CITAR ESTE ARTIGO: CARREIRA, Vivina Almeida; BURGEILE, Odete. Teaching english for agriculture through proverbs in 11 and I2. Revista do GEL, v. 14, n. 3, p. 154-168, 2017. Disponível em: https://revistadogel.gel.org.br/.

DOI: $\underline{\text { http://dx.doi.org/10.21165/gel.v14i3.1876 }}$

Submetido em: 30/07/2017. | Aceito em: 09/11/2017. 